\title{
Occult extra-adrenal pheochromocytoma in the urinary bladder
}

\author{
Victor Siang Hua Chan, ${ }^{\circledR}$ Derek Lok Hei Chan, Shui Yee Hui, Wendy Wai Man Lam
}

Radiology, Queen Mary Hospital, Hong Kong

\section{Correspondence to}

Dr Victor Siang Hua Chan, chanshvictor@gmail.com

Accepted 20 February 2019

\section{DESCRIPTION}

Pheochromocytoma is an uncommon neuroendocrine tumour arising from the chromaffin cells associated with increased catecholamine production. More than $85 \%$ of the tumours are infradiaphragmatic in location, with para-aortic region being the most common site. ${ }^{1}$

Extra-adrenal pheochromocytoma

(EAP) accounts for $10 \%-15 \%$ of pheochromocytoma in adults and $30 \%-40 \%$ in children. ${ }^{2}$ EAP is sporadic and tends to be larger than the adrenal counterpart at the time of detection. ${ }^{3}$

Herein, the authors report a rare case of occult bladder EAP that evaded initial imaging modalities due to diagnostic pathway loopholes. A 6-year-old girl had presented with a 1-year history of hypertension, diaphoresis and episodic postmicturition headache. Urinalysis revealed elevated norepinephrine, epinephrine and vanillylmandelic acid levels, highly suspicious for pheochromocytoma. The contrast CT scan of the abdomen and ultrasound (US) for renal artery stenosis performed at another hospital did not include the pelvis in the scanned region and were otherwise unremarkable. Fluorodeoxyglucose-positron emission tomography (PET) showed absent pelvic uptake. The $\mathrm{I}^{131}$-metaiodobenzylguanidine scan was negative. The diagnosis was finally suggested on $\mathrm{C}^{11}$ L-3,4-dihydroxyphenylalanine PET scan of which a focus of increased uptake was noted at the anterior bladder.

A pelvic US demonstrated a $6 \mathrm{~cm}$ hypoechoic intramural mass at the dome of the urinary bladder with preserved epithelial lining (figure 1). Colour Doppler imaging (figure 2) revealed prominent peripheral vessels which extended to the rest of

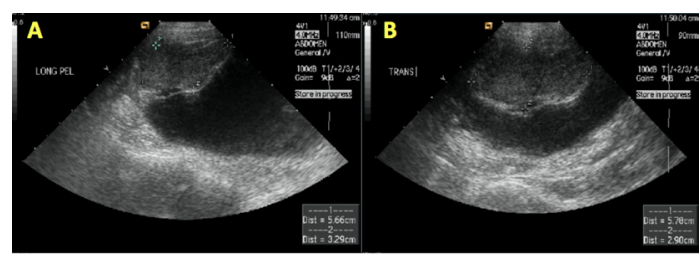

Figure 1 An ultrasound of the pelvis of a 6-year-old girl, demonstrating a hypoechoic intramural soft tissue mass at the urinary bladder dome, measuring $5.8 \times 2.9 \times 5.7 \mathrm{~cm}$. Sonographic images are represented in $(A)$ the sagittal view and $(B)$ the transverse view.

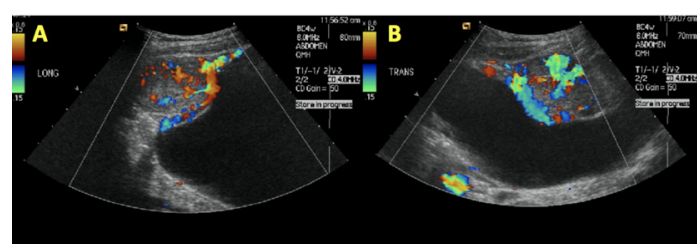

Figure 2 Colour Doppler imaging of the bladder mass $(A, B)$, demonstrating intralesional vascularity. Prominent peripheral vessels are seen extending to the rest of the bladder wall.

the bladder wall. No vascular communication with the adjacent bowel loops was seen. The histopathological diagnosis of EAP was confirmed after an uneventful surgical resection of the bladder tumour.

\section{Learning points}

Although rare, urinary bladder pheochromocytoma should be considered as one of the possible extra-adrenal sites.

- The authors recommend the inclusion of pelvic imaging as part of the routine protocol for the screening of pheochromocytoma.

- This case illustrates the high-spatial resolution and multiplanar capability of ultrasound evaluation, which mirrored the intraoperative findings in this case.

Contributors VSHC and DLHC contributed to the drafting of the manuscript. SYH contributed to the acquisition of the sonographic images and supervision of the manuscript. WWML supervised the writing of the manuscript.

Funding The authors have not declared a specific grant for this research from any funding agency in the public, commercial or not-for-profit sectors.

Competing interests None declared.

Patient consent for publication Not required.

Provenance and peer review Not commissioned; externally peer reviewed.

\section{REFERENCES}

1 Ansari MS, Goel A, Goel S, et al. Malignant paraganglioma of the urinary bladder. A case report. Int Urol Nephrol 2001;33:343-5.

2 Purandare NC, Sanghvi DA, Jhambekar NA. Pheochromocytoma of the urinary bladder. J Ultrasound Med 2005;24:881-3.

3 Vyas S, Kalra N, Singh SK, et al. Pheochromocytoma of urinary bladder. Indian J Nephrol 2011;21:198-200. 
Images in...

Copyright 2019 BMJ Publishing Group. All rights reserved. For permission to reuse any of this content visit https://www.bmj.com/company/products-services/rights-and-licensing/permissions/

BMJ Case Report Fellows may re-use this article for personal use and teaching without any further permission.

Become a Fellow of BMJ Case Reports today and you can:

- Submit as many cases as you like

- Enjoy fast sympathetic peer review and rapid publication of accepted articles

Access all the published articles

- Re-use any of the published material for personal use and teaching without further permission

For information on Institutional Fellowships contact consortiasales@bmjgroup.com

Visit casereports.bmj.com for more articles like this and to become a Fellow 